\title{
ANTIFUNGAL ACTIVITY OF THE AQUEOUS AND ETHANOLIC EXTRACTS OF THONNINGIA SANGUINEA VAHL. (BALANOPHORACEAE)
}

\author{
*Ouattara karamoko ${ }^{1,2}$, Koné tiegbe ${ }^{1}$, Yeo dodehe ${ }^{1}$, Coulibaly adama ${ }^{1}$ \\ ${ }^{1}$ Laboratoire de Pharmacodynamie Biochimique, UFR Biosciences, Université Felix Houphouet Boigny-Abidjan, Côte d'Ivoire \\ ${ }^{2}$ Laboratoire de Microbiologie du Centre Ivoirien Anti-Pollution (CIAPOL), Abidjan ; Côte d'Ivoire. \\ *Corresponding author: Ouattara Karamoko; 22 BP 582 Abidjan 22, Côte d'Ivoire; e-mail: ouattkara@yahoo.fr
}

Received 03 Dec 2012; Review Completed 11 Jan 2013; Accepted 11 Jan 2013, Available online 15 Jan 2013

\begin{abstract}
The aim of this study was to evaluate the in vitro antifungal properties of Aqueous and Ethanolic extracts of Thonningia sanguinea Vahl (Balanophoraceae). Thisparasitic plant is commonly used in Ivory Coast and in many other parts of West Africa to treat dermatitis, diarrhea and asthma. Aqueous and Ethanolic extracts of Thonningia sanguinea were evaluated for their antifungal activities by double dilution method against three strains: Candida albicans (C. albicans) Cryptococcus neoformans (C.neoformans) and Aspergillus fumigatus (A. fumigatus). The phytochemical screening was also evaluated. Antifungal tests indicated that the different extracts studied were active on all selected strains, but their inhibitory activity was more pronounced on $C$. neoformans compared with A. fumigatus and C. albicans. In addition, our works revealed that the aqueous extract (ATE) was a fungicide on three tested germs while ethanolic extract (ETE) was fungicidal on $C$. neoformans and fungistatic on the two strains. The phytochemical revealed the presence of alkaloids, tannins and flavonoids. The results showed that the aqueous extract and ethanolic extract of Thonningia sanguinea Vahl. (Balanophoraceae) exerted an antifungal effect on $C$. neoformans, A. fumigatus and $C$. albicans and supports its traditional use in herbal medicine.

Keywords: Thonningia sanguinea, fungicidal, fungistatic.
\end{abstract}

\section{INTRODUCTION}

Since 1980, HIV/AIDS is associated with the increase of opportunist diseases such ascryptococcoses, candidiases and aspergilloses. These pathologies are causing today many deaths around the world ${ }^{1}$.

According to Breuil and al. $^{2}$, the germs responsible for these diseases developed more resistances against drugs. This situation was associated with high cost of these pharmaceutical drugs. Medicinal plants are known to produce certain bioactive molecules which react with other organisms in the environment; inhibiting bacterial or fungal growth. Antimicrobial properties of medicinal plants are being increasingly reported from different parts of the world. More than $75 \%$ of the African population uses the plants to treat disease ${ }^{3}$.

Thonningia sanguinea extract has been used for centuries as a popular method for treating several health disorders such as fungal and enteritis. The effects of Thonningia sanguinea aqueous extract on some microorganisms including $C$. neoformans has been reported in some studies in the area of pharmacology ${ }^{4}$.

In order to complete the previous work on the antifungal activity of Thonningia sanguinea, we studied the properties of aqueous and ethanolic extracts on the in vitro growth of $C$. albicans, A. fumigatus and C. neoformans.

\section{MATERIAL AND METHODS}

\section{Plant material}

Thonningia sanguinea flowers and bracts were collected in Sandégué, Côte d'Ivoire (West Africa) and identified by Pr
Aké-Assi of the Department of Botany, University Felix Houphouet-Boigny of Cocody-Abidjan. A voucher specimen (Voucher no. 14162) is deposited in the herbarium of National Floristic Garden of Abidjan.

\section{Fungal strains}

The seeds tested were provided by the CeDReS (Diagnostic and Research Center on AIDS), Abidjan. Candida albicans, Cryptococcus neoformans and Aspergillus fumigatus were used in this study. These germs have been isolated from patients from the infectious Diseases Department of Hospital of Treichville (Abidjan). Table 1 represented the origins of the strains.

Table 1: Identification and origin of the fungal strains

\begin{tabular}{|l|c|c|}
\hline \multicolumn{1}{|c|}{ Strains } & Abbreviations & Origin \\
\hline Candida albicans & C. albicans & Vaginal swab \\
\hline Aspergillus fumigatus & A. fumigatus & Blood \\
\hline $\begin{array}{l}\text { Cryptococcus } \\
\text { neoformans }\end{array}$ & C. neoformans & skin \\
\hline
\end{tabular}

\section{Extraction procedure}

The freshly collected flowers and bracts of the plant were air dried at room temperature and powdered. Briefly $100 \mathrm{~g}$ of powder was soaked in $1 \mathrm{~L}$ distilled water for $24 \mathrm{~h}$ with constant stirring. The suspension was further filtered through Whatman (No. 1) filter paper. The filtrate was 
concentrated with a rotary evaporator to obtain the aqueous extract.

\section{Antifungal tests}

The cultures of different "strains" of fungi have been carried out on Sabouraud agar (OXOÏD). The inclusion of plant extracts in the agar was made using the method of the double dilution agar slopes ${ }^{5 ; 6}$. Both extracts (aqueous and ethanol) were tested separately. Each test series consisted of eight tubes containing the plant extract and two control tubes in which one is without a plant extract used to monitor the growth of germs, and the other germ-free tube and without plant extract was used as sterility controls to the culture medium. For the eight test tubes, concentrations of plant extract ranged from 100 to $0.78 \mu \mathrm{g} / \mathrm{mL}$ binding by a geometrical reason of $1 / 2$.

After incorporation of the extract to the agar, all ten tubes of each series were sterilized in an autoclave at $121^{\circ} \mathrm{C}$ for 15 minutes and then inclined to room temperature to allow cooling and solidification of the agar ${ }^{7}$. For each series, the antifungal tests were carried out using a previously prepared inoculum $\left(10^{5}\right.$ cells $/ \mathrm{mL}$ ). Ketoconazole USP (20 $\mathrm{mg}$ ) was used as a positive control. All cultures were incubated at $30^{\circ} \mathrm{C}$ for 48 hours. After this period, the colonies were counted and growth in experimental tubes was determined. Growth in the eight tubes of each experimental series was assessed as a percentage of survival compared to $100 \%$ survival in the control tube growth control ${ }^{8}$. Treatment of experimental data was used to determine the antifungal parameters $\left(\mathrm{MFC}, \mathrm{IC}_{50}\right)$.

\section{Phytochemical screening}

To search for polyterpens, the reagent was that of Liebermann. Polyphenols have been detected by the reaction to ferric chloride. The reaction to cyanidin helped to highlight the flavonoids. For tannins, their presence has been detected by the Stiasny reagent. Quinone groups free or combined were highlighted through the reagent Borntraeger. The alkaloids were revealed by the Dragendorff or Bouchardat reagents. And saponins have been identified by measuring the height of foam after shaking.

\section{Statistical analysis}

The experiment was repeated for 3 times for each treatment used and data were analyzed by analysis of variance test (ANOVA) followed by least significant difference test (LSD).

\section{RESULTS AND DISCUSSION}

After incubation for 48 hours at $30^{\circ} \mathrm{C}$, extracts exerted a gradual decrease in the number of colonies of each organism tested compared to the growth control (Figures 1, 2 \& 3). Taking into account both $\mathrm{MFC}$ and $\mathrm{IC}_{50}$, the aqueous extract presented the highest sensitivity with $C$. neoformans $\left(\mathrm{MFC}=12.5 \mathrm{mg} / \mathrm{mL}, \quad \mathrm{IC}_{50}=1.66 \mathrm{mg} / \mathrm{mL}\right)$ followed respectively by $C$. albicans $(\mathrm{MFC}=50 \mathrm{mg} / \mathrm{ml}$, $\mathrm{IC}_{50}=8 \mathrm{mg} / \mathrm{mL}$ ) and A. fumigatus $\left(\mathrm{MFC}=25 \mathrm{mg} / \mathrm{ml}, \mathrm{IC}_{50}\right.$ $=4.33 \mathrm{mg} / \mathrm{mL}$ ). the antifungal parameters were shown on table 2 . In addition, a new media seeding swabs taken from the surface of each of the circles representing the MIC showed no colony growth on these media after 48 hours of incubation at $30^{\circ} \mathrm{C}$. We can then deduce that the Thonningia sanguinea aqueous extract was fungicidal for all strains tested. These results are in agreement with those of de Souza et al. ${ }^{9}$. These authors showed that the aqueous extract of this plant had a fungicidal effect on various fungal organisms including C. albicans and A. fumigatus.

The result revealed the presence of colonies of strains grown with the exception of $C$. neoformans. We deduced that the ethanolic extract exerted a fungistatic activity against $C$. albicans and $A$. fumigatus and fungicidal activity against $C$. neoformans. This result was similar to those obtained by Ouattara and al. ${ }^{10}$

able2: Antifungal parameters of the extracts and Ketoconazole

\begin{tabular}{|l|l|c|c|}
\hline \multicolumn{2}{|c|}{} & \multicolumn{2}{|c|}{ Anti-fungal parameters } \\
\hline \multirow{4}{*}{ ETA } & Fungal strains & MFC (mg/mL) & IC $_{\mathbf{5 0}}(\mathbf{m g} / \mathbf{m L})$ \\
\cline { 2 - 4 } & C. albicans & 50 & 8 \\
\cline { 2 - 4 } & A. fumigatus & 25 & 4.33 \\
\cline { 2 - 4 } & C. neoformans & 12,5 & 1.66 \\
\hline \multirow{5}{*}{ Ketoconazole } & C. albicans & 6.25 & 0.7 \\
\cline { 2 - 4 } & A. fumigatus & 25 & 1.2 \\
\cline { 2 - 4 } & C. neoformans & 3.125 & 0.4 \\
\cline { 2 - 4 } & A. fumigatus & 0.0480 & $8.26 .10^{-3}$ \\
\cline { 2 - 4 } & C. neoformans & 0.0125 & $3.04 .10^{-3}$ \\
\hline
\end{tabular}

ETA : Aqueous extract ; ETE : Ethanolic extract 


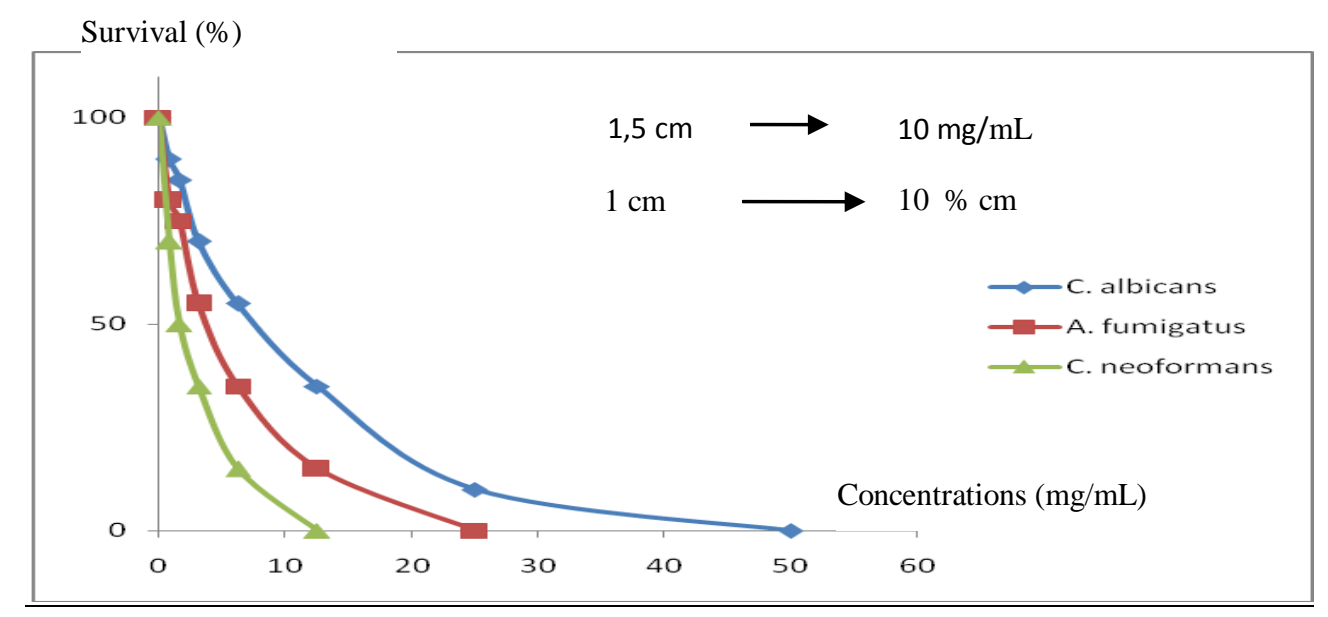

Figure 1: Antifungal activity of the aqueous extract of Thonningia sanguinea

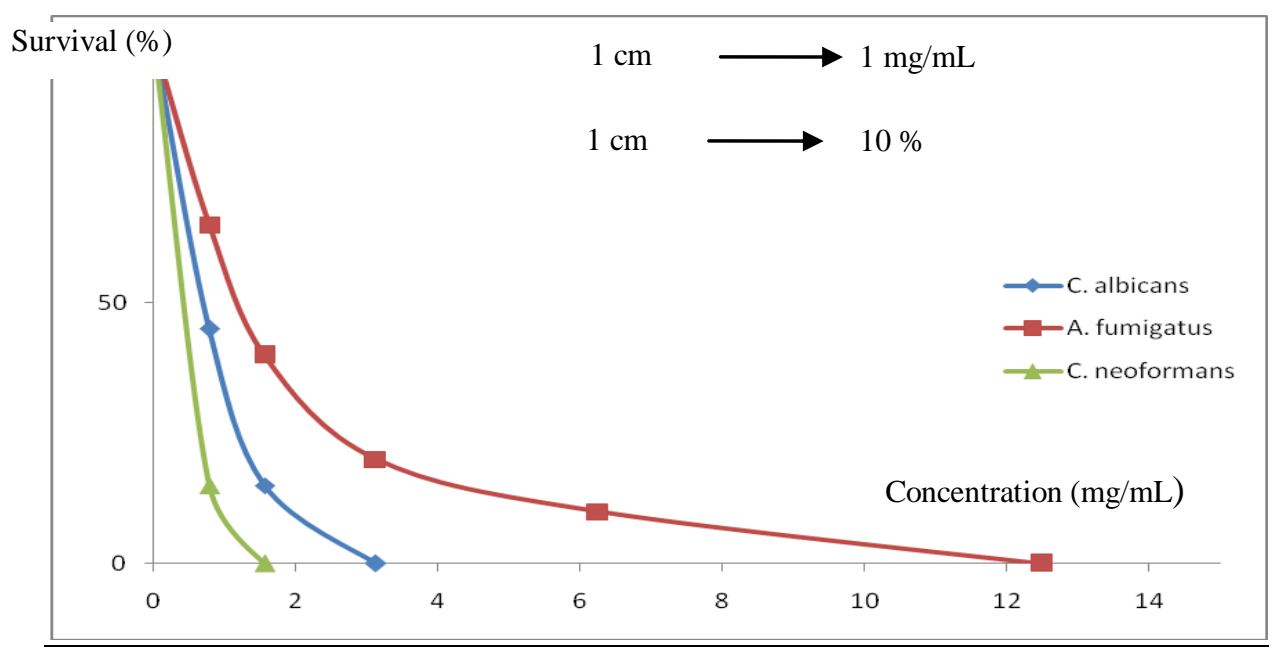

Figure 2: Antifungal activity of the ethanolic extract of Thonningia sanguinea

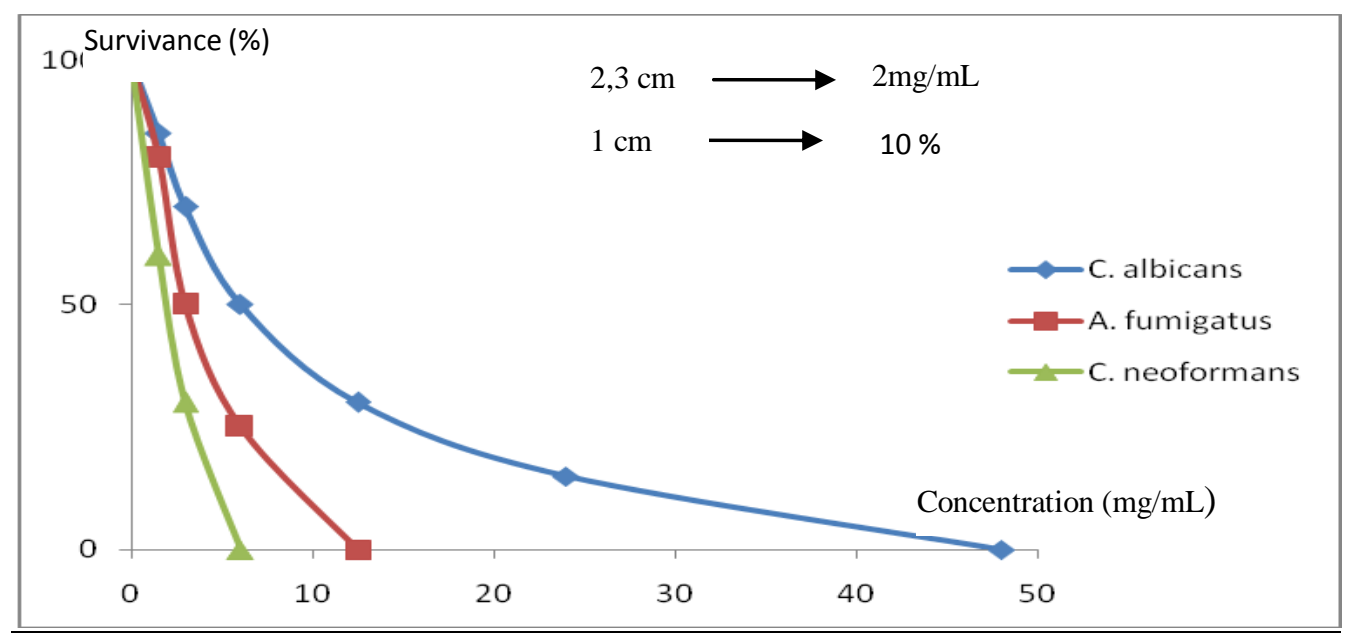

Figure 3: Antifungal activity of ketoconazole

Analysis of the results based on MFC showed that the ethanolic extract was more active than the aqueous extract. In fact, the antifungal parameter values of the ethanolic extract were closer to those of ketoconazole (reference). In the choice of appropriate solvents, our findings supported the use of ethanol by several authors ${ }^{11 ; 12}$. Moreover, the ratio of the values of the CMF obtained with aqueous extract and those of the ethanolic extract gave 8, 4 and 1 
respectively for $C$. albicans, $C$. neoformans and $A$. fumigatus, suggesting that the ethanolic extract was 8 times more active than the aqueous extract with $C$. albicans and 4 times with $C$. neoformans. A. fumigatus presented the same sensitivity in the presence of both extracts. This different sensibility between the aqueous and ethanolic extracts could be explained by the chemical component.

Table 3: Phytochemical components of Thonningia sanguine a aqueous and ethanolic extracts

\begin{tabular}{|l|c|c|}
\hline $\begin{array}{l}\text { Phytochemical } \\
\text { components }\end{array}$ & \multicolumn{2}{|c|}{$\begin{array}{c}\text { Thonningia sanguinea } \\
\text { extracts }\end{array}$} \\
\hline & $\begin{array}{c}\text { Aqueous } \\
\text { extract }\end{array}$ & $\begin{array}{c}\text { Ethanolic } \\
\text { extract }\end{array}$ \\
\hline Alkaloids & + & ++ \\
\hline Gallic tannins & - & - \\
\hline Cathechic tannins & ++ & +++ \\
\hline Flavonoids & + & ++ \\
\hline Saponins & ++ & + \\
\hline Quinones & ++ & + \\
\hline Polyphenols & ++ & ++ \\
\hline Sterol and Polyterpens & - & - \\
\hline \multicolumn{2}{|l}{$-:$ Absence; }
\end{tabular}

+ Presence in low concentration;

++ (presence in moderate concentration); +++ Presence in high concentration

Bagré and al. ${ }^{13}$ showed that alcoholic extracts were more active than the aqueous extracts because this solvent possessed a better extraction of less polar compounds such as terpens or alkaloids and flavonoids. Chemical analysis results (Table 3) revealed the presence of various compounds including alkaloids, tannins and flavonoids. Those compounds possessed antimicrobial properties ${ }^{14 ; 15}$.

\section{REFERENCES}

1. Ackah JAAB, Kra AKM, Zirihi GN and Guede-Guina F : Evaluation et essais d'optimisations de l'activité anticandidosique de terminalia catappalinn (tekam3), un extrait de combretaceaede la pharmacopée ivoirienne. Bull. Soc. R. Sci. Liège 2008, 77 : 120-136.

2. Breuil J, Brisabois A, Arnaud L, Fremy S and Collatz E: Antibiotic resistance in salmonellae isolated from human and animals in France : comparative data from 1994 and 1997. J Antimicrob Chemoth 2000, 46: 965-971

3. Rai PK, Mehta S, Gupta RK and Watal G: A Novel Antimicrobial Agents Trichosanthes Diocia. International Journal of Pharma and Bioscience, 2010, 1: 1-9.

4. Ouattara B, Kra AM, Coulibaly A, Guede-Guina F: Efficacité de l'extrait éthanolique de Thonningia sanguinea sur Cryptococcusneoformans. Santé, 2007, 17 : 219-222.

5. Guede-Guina F, Vangah-Mandah M, Bonga GM and de Souza C : Activité antimicrobienne d'un extrait végétal contre les germes opportunistes au cours du SIDA. Médecines et Pharmacopées Africaines, 1995, 1: 13-20

6. Zihiri GN and Kra AKM: Evaluation de l'activité antifongique Microglossapirifolia (LAMARCK) O. kuntze (Asteraceae) « pymi » sur la croissance in vitro de candida albicans. Rév Méd Pharm Afr 2003, 17: 11-19.

7. Vangah-Mandah M, Dje M, Guede-Guina F and de Souza C : Evaluation des effets antimicrobiens et cytotoxiques des extraits aqueux totaux de THOS. Revue de Médecine et Pharmacopées Africaines 1994, 8 : 153-157.
Most of these compounds were more concentrated in the ethanolic extract. This observation confirmed the important activity of this extract compared to the aqueous extract. Moreover the aqueous extract appeared to be the least sensitive against $C$. albicans. However, in the presence of the ethanolic extract, this strain was more sensitive than A. fumigatus. The inhibitory effect of both extracts was more pronounced against $C$. neoformans than the two strains ( $C$. albicans and A. fumigatus).

\section{CONCLUSION}

Our work had highlighted the antifungal properties of aqueous extracts and ethanol of Thonningia sanguinea against $C$. albicans, A. fumigatus and $C$. neoformans, three fungal potentially pathogenic germs. Their action was either fungicidal or fungistatic depending on the germ. Ethanolic extract was more active than the aqueous total extract, which contained moreactive (s) principle (s) of the plant. These results could be used for the purification of the active principle.

\section{COMPETING INTERESTS}

The authors declare that they have no competing interests.

\section{ACKNOWLEDGEMENTS}

The authors are indebted to Professor Aké-Assi Laurent (Laboratory of Botany, Unité de Formation et de Recherche -Biosciences, University of Felix Houphouet Boigny-Abidjan, Côte d'Ivoire) for botanical identification of Thonningia sanguinea Vahl. (Balanophoraceae). They also grateful to the CeDReS (Diagnostic and Research Center on AIDS, Abidjan) for the strains,

8. Laurent F, Sapin V, Vincent CM, Campagni HP: Les Aspergilloses. Lyon pharm 1992, 43 : 339-349.

9. de Souza C. and Amegavi KK : Etude de L'activité microbienne des extraits aqueux totaux de dix plantes médicinales. Les Revues de Médecines et Pharmacopées Africaines 1993, 7 : 109-114.

10. Ouattara K, Coulibaly A, N'guessan JD, Guede-Guina F, Djaman AJ : Effets de Thonningia sanguinea (THOS) sur la qualité des œufs et le taux de ponte des poules au cours d'une salmonellose expérimentale à Salmonella enterica serotype enteridis lysotype 6. Agr Afr 2007, 19: 21-28.

11. Jonathan SG and Fasadi IO: Antimicribial activities of two Nigerian ediblemacrofungi, Lycoperdonpusilum and $L$. giganteum. Afr J Biomed Res 2003, 6: 85-90.

12. Dulger G. and Aki C: Antimicrobial activity of the leaves of Endemic Stachyspseudopinardii in Turkey. Trop J Pharm Res 2009, 8: 371-375

13. Bagre I, Bahi C, Ouattara K, Zirihi-Guede N, Djaman AJ, Coulibaly A et N'guessan JD : Étude botanique et exploration de l'activité antifongique de Morindamorindoides(Baker) MilneRedh. sur la croissance in vitro de Cryptococcus neoformans. Phytothérapie 2011, 9: 136-141

14. Cowan MM: Plants products as anti-microbial activity. Clinical Microbiology Reviews 1999, 4: 564-582.

15. Kolodzie H, Kayser O, Latte PK and Ferreira D: Evaluation of the antimicrobial potency of tannins and related compounds using the rnicrodilution broth method. Planta Med 1999, 65: 444 $-446$. 